\title{
Influence of Pressure on High-Temperature Coal Pyrolysis Property and Coke Particle Formation at Entrained Flow Coal Gasifier Conditions
}

\author{
Shiro KAJITANI ${ }^{* 1}$, Nobuyuki SuZUKI ${ }^{* 1, * 3}$, Saburo HARA*1, Hiroyuki NAKAGAWA ${ }^{* 2}$, and Kouichi MiURA*2 \\ (Received March 29, 2004)
}
噴流床ガス化炉内条件における石炭の高温熱分解特性とコーク微粒子の生成挙動に対する圧力影響 梶谷史朗*1，鈴木伸行*1,3，原 三郎*1, 中川浩行*2，三浦孝一*2

\begin{abstract}
The coal pyrolysis behavior, that is the initial reaction in the coal gasifier, is investigated to clarify phenomena in the gasifier of IGCC. Since pressurized entrained flow gasifiers are adopted for the almost all IGCC processes for large-scale power generation and these gasifiers are operated at a pressurized reducing atmosphere and high temperature, the influence of the pyrolysis temperature and pressure on the composition and properties of the pyrolysis product was examined. As a result of rapid pyrolysis tests for three types of bituminous or semi-bituminous coal using a pressurized drop tube furnace facility (PDTF) in nitrogen gas flow at high temperatures of over 1000 degrees Celsius and at high pressures of under $2.1 \mathrm{MPa}$, the yield of the volatilized gas components decreased when pyrolysis pressure increased. The product char of pyrolysis tests was formed many more than fixed carbon in coal, and contained a large amount of fine particulates of carbon like coke or soot. For some coal types, the $\mathrm{CO}_{2}$ gasification reactivity of the fine particulates was so lower than that of the char particles originated from fixed carbon that it could be said that the clarification of the formation mechanism of coke is important. The amount of the coke particulates existing outside char particles at pressurized pyrolysis tests was less than that of the coke particulates at $0.15 \mathrm{MPa}$ because of deceleration of volatilization at primary pyrolysis reactions. Furthermore, it was confirmed that the coke particulates were also formed at the conditions where gasifying agent existed like the inside of gasifiers.
\end{abstract}

\section{Key Words}

Coal gasification, Pyrolysis, Volatile matter yield, Coke, Gasification reactivity

\section{1. 緒 言}

現在開発の進んでいる石炭ガス化複合発電 (IGCC) プラン トは, 高効率で環境への適応性が高く将来必要不可欠な石炭 火力発電技術であり, 空気吹きや酸素吹きの様々な形式のガ ス化炉が開発されている。ほとんどの場合で加圧噴流床ガス

* 1 Central Research Institute of Electric Power Industry (CRIEPI), Energy Engineering Research Laboratory 2-6-1 Nagasaka, Yokosuka, Kanagawa 240-0196, Japan

* 2 Kyoto University, Department of Chemical Engineering Katsura Campus, Nishikyo-ku, Kyoto 615-8510, Japan

* 3 Currently, Electric Power Development Co., Ltd. (J-power), Technology Development Center 1, Yanagisaki-machi, Wakamatsu-ku, Kitakyushu, Fukuoka 808-0111, Japan
化炉が採用されており，ガス化炉内は高温加圧の還元雲囲気 となるので, ガス化炉の設計や性能評価, 炉内現象の予測の ためには，このような高温加圧下での微粉炭の挙動を解明す る必要がある。 ガス化炉内での石炭の反応は, 急速熱分解反応, 揮発分の
* 1 (財)電力中央研究所エネルギー技術研究所 于 240-0196 神奈川県横須賀市長坂 2-6-1
*2 京都大学大学院工学研究科化学工学専攻 于 615-8510 京都府京都市西京区京都大学桂
* 3 現在, 電源開発株式会社技術開発センター 干 808-0111 福岡県北九州市若松区柳崎町 1 番 
気相反応, チャーとガス化剂 (酸素, 二酸化炭素, 水蒸気) と の気固反応に分けて実験, 解析されることが多く, これまで に熱分解条件がチャーのガス化反応性へ与える影響を明らか にし1)，チャーガス化反応のモデル化2) 3) を行ってきた。さら に, 熱分解反応のモデル化も重要であり, 様々なモデルが提 案されているが4) 6), 高温かつ高圧下での実験結果の報告は ほとんどない。また， $1000^{\circ} \mathrm{C}$ 以上の高温では微粒炭素（コー クあるいはスート)の生成が見られ, Miuraらはその反応性の 違いからチャーとコークの生成割合を検討した ${ }^{7)}$ 。

そこで, 本研究では気流層型反応装置 (PDTF : Pressurized Drop Tube Furnace）を用いて IGCC ガス化炉内条件を想定し た石炭熱分解実験を実施し高温熱分解における熱分解特性の 圧力影響を明らかにするとともに，コークの生成特性と チャーやコークのガス化反応性の差異を検討して噴流床ガス 化炉の設計や性能評価においてこれまでには考慮されてこな かったガス化炉内でのコークの挙動の重要性を示した。

\section{2. 実 験}

\section{1 石炭の高温加圧熱分解実験}

供試炭はTable 1に示す 3 炭種の瀝青炭および亜瀝青炭で, ガス化に向くと見られる燃料比の比較的低い石炭を選択した。

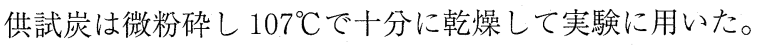

高温熱分解実験に用いたPDTF 装置 (Fig. 1) は, 所定の温 度，圧力，雲囲気ガス流に設定した管状電気炉内に微粉炭試 料を気流搬送で投入することで急速昇温を可能にした気流層 型反応装置である。熱分解実験方法は前報1) と同様に，窒素 ガスを流した炉内へ $80 \sim 200 \mathrm{~g} / \mathrm{h}$ の微粉炭を投入して熱分解 し，熱分解生成物（生成ガスおよび生成チャー）は炉底から 挿入した水冷式サンプリングプローブにより等速吸引で捕集 した。炉上部の水冷式給炭管を加熱部付近まで挿入すること により，数千 ${ }^{\circ} \mathrm{C} /$ 秒以上の昇温速度が得られた。

IGCC用ガス化炉の高温加圧炉内条件を考慮して実験条件を 決定し, PDTF 炉内温度は $1000^{\circ} \mathrm{C} \sim 1400^{\circ} \mathrm{C}$, 炉内圧力は 0.15 $\mathrm{MPa} \sim 2.1 \mathrm{MPa}$ の範囲で実験した。炉内供給ガスは熱分解実験 では窒素のみとしたが，ガス化剤の存在によるコーク生成量 の変化を見るため，一部条件では希薄酸素を供給した。

Table 1 Properties of test coals

\begin{tabular}{lccc}
\hline & Coal WO & Coal SK & Coal BT \\
\hline Moisture(wt\% air dried basis) & 2.96 & 7.2 & 7.6 \\
Proximate Analysis (wt\% dry basis) & & \\
Ash & 10.0 & 5.1 & 5.3 \\
Volatile Matter & 43.0 & 39.3 & 46.6 \\
Fixed Carbon & 47.0 & 55.6 & 48.1 \\
Fuel Ratio (=FC/VM) & 1.1 & 1.4 & 1.0 \\
Ultimate Analysis (wt\% dry ash-free basis) & & \\
C & 79.0 & 77.5 & 75.5 \\
H & 5.9 & 5.0 & 5.3 \\
O & 12.8 & 16.4 & 17.1 \\
N & 1.6 & 0.9 & 1.7 \\
S & 0.7 & 0.2 & 0.4 \\
\hline
\end{tabular}

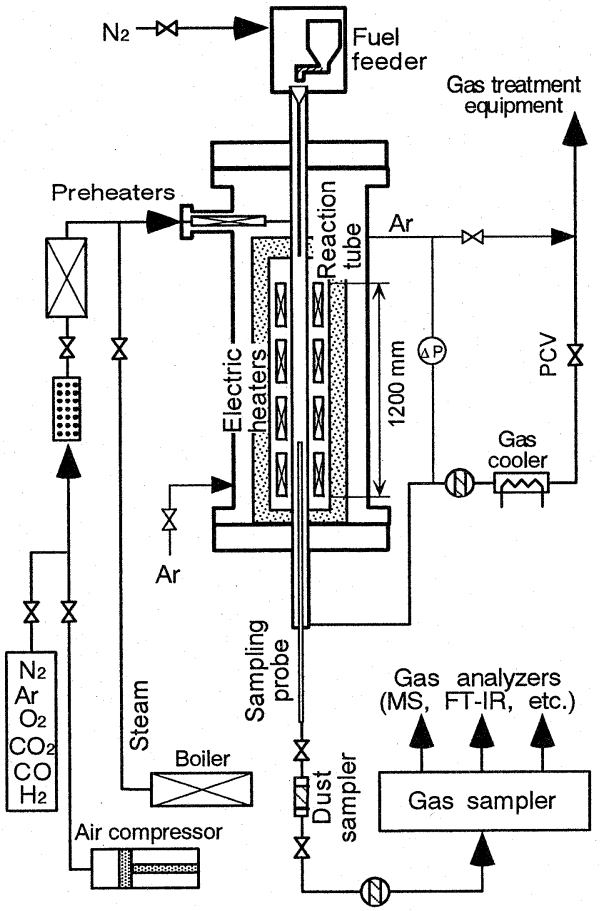

Fig. 1 Schematic of the PDTF facility

サンプリングした生成ガスはガスクロマトグラフを用いて $\mathrm{H}_{2}$ と $\mathrm{CO}$ を, ND-IR 式連続計で $\mathrm{CO}_{2}$ を, 四重極質量分析計に より $\mathrm{CH}_{4}$ と $\mathrm{H}_{2} \mathrm{O}$ を連続分析し, 各条件で静定した時の生成ガ 又組成を得た。一部条件においては塩化カルシウムの吸湿管 による水分測定とタールトラップによるタール濃度測定を 行った。

\section{2 熱分解生成チャーのキャラクタリゼーション}

チャーとともに生成したコーク微粒子を分離するため, 高 温加圧熱分解試験に抒いてサンプリングプローブで捕集した 生成チャーを 60 mesh $(250 \mu \mathrm{m})$ の篩で前報 ${ }^{1)}$ と同様に乾式 分級し，凝集性の高い微粒子（篩上）と低い粒子（篩下）と に分けた。また, 走査型電子顕微鏡 (S-3500N, 日立製作所社 製）による表面観察や，レーザー回折法による粒径分布測定 (SK-LMS PRO-30，セイシン企業社製)を行った。さらに, 熱 天秤（TG）を用いて TPR 法 (Temperature Programmed Reaction Technique) によるチャーやコークのガス化実験を行っ た。使用したTGは上血式差動型の天秤と白金抵抗炉から成る 加圧型示差熱天秤 (マック・サイエンス社製) で, 約 $5 \mathrm{mg} の$ 試料を静置して二酸化炭素ガスを流しながら昇温速度 $10^{\circ} \mathrm{C} /$ minで加熱し, 重量減少率を観測した。

\section{3. 結果と考察}

\section{1 高温加圧下における熱分解特性}

$0.15 \mathrm{MPa}$ と $2.1 \mathrm{MPa}$ の圧力において $1000^{\circ} \mathrm{C}, 1200^{\circ} \mathrm{C}, 1400$ ${ }^{\circ} \mathrm{C}$ で高温熱分解した時の生成ガス組成分析結果から求めた各 種ガス成分の収率の実験結果をFig. 2 に示した。Fig. 3 には, Thermfact GTT Technologies 社の熱化学計算ソフト FactSage 5.28) 9) を用いて推算した各実験条件における $\mathrm{C}, \mathrm{H}, \mathrm{O}$ 系 $\left(\mathrm{N}_{2}\right.$ 


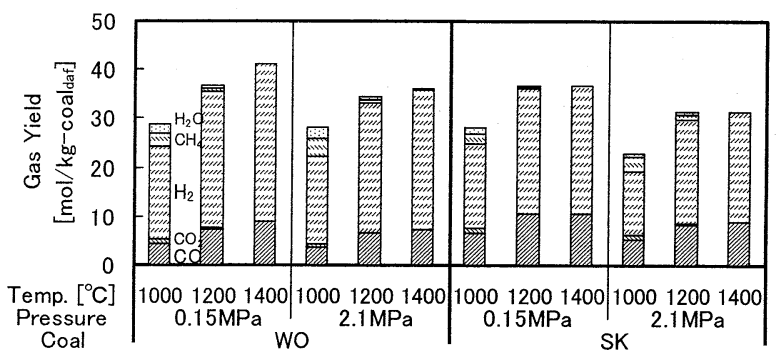

Fig. 2 Gas yield at high-temperature pressurized coal pyrolysis tests (Residence time through heating zone is 4.3 or $5.2 \mathrm{~s}$ at $0.15 \mathrm{MPa}$, and $4.2,4.7,5.1 \mathrm{~s}$ at $2.1 \mathrm{MPa}$ )

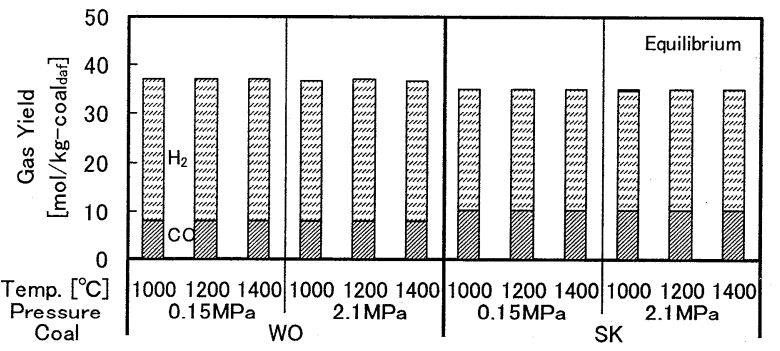

Fig. 3 Predicted gas yieid from chemical equilibrium

ベース)の化学平衡時のガス収率を示した。なお, Coal BTの 実験結果については，別途論文7)に記載の通りである。平衡 計算によると， $1000^{\circ} \mathrm{C}$ 以上の高温熱分解では微粉炭中のす心゙ ての酸素と水素は揮発してほぼ $\mathrm{CO}$ と $\mathrm{H}_{2}$ のみが生成され，圧 力による生成ガス収率の違いはほとんどないことが分かる。 しかし, 実験結果では $1000^{\circ} \mathrm{C} て ゙ も ~ \mathrm{CO}$ や $\mathrm{H}_{2}$ 以外に $\mathrm{CO}_{2}, \mathrm{CH}_{4}$, 水蒸気と微量の夕ールの生成が見られた。 $1200^{\circ} \mathrm{C}$ 以上での生 成ガスは平衡計算と同様に $\mathrm{CO}$ と $\mathrm{H}_{2}$ とにまでほぼ完全に分解 されたが，収率には圧力の影響が見られ，2.1 MPaでの生成ガ ス量は $0.15 \mathrm{MPa} よ り も 10 \%$ 前後減少した。

Fig. 2 には炉内加熱部の滞留時間が $4 \sim 5$ 秒の実験結果を示 したが, $0.15 \mathrm{MPa}$ や $0.6 \mathrm{MPa}$ の圧力で $1400^{\circ} \mathrm{C}$ においてンプ リングプローブを上昇させて滞留時間を 1 秒まで短くしても 滞留時間による収率の変化はほとんど見られず，既に熱分解 は完了していた。一方, $2.1 \mathrm{MPa}$ では加圧により生成ガス収率 が減少したが，これは熱分解速度が低下して 5 秒程度では平 衡に達しないためと考えられる。

次に, 固体粒子側である生成チャー中へ残留する炭素の収 率をサンプリングガス基準で計算したところ，Fig. 4に示した 通り平衡計算とほぼ同程度だが, 加圧にすることで生成ガス

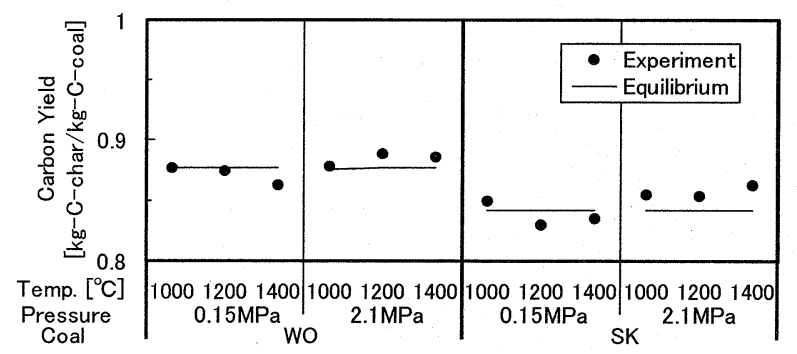

Fig. 4 Carbon yield in solid particle at high-temperature pressurized coal pyrolysis tests and predicted yield from chemical equilibrium

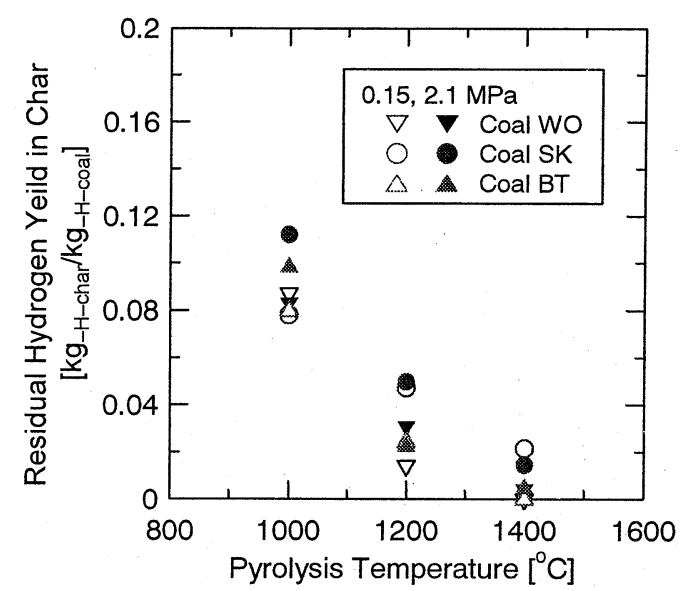

Fig. 5 Hydrogen yield in solid particle at high-temperature pressurized coal pyrolysis tests

収率が減少した分だけ生成チャー側への炭素残留率（炭素収 率）が増加した。実験で得られた炭素収率は工業分析の固定 炭素（Table 1）に相当する量よりも大幅に大きく，固定炭素 を上回る炭素分が生成チャーとして残留したことになる。

平衡計算ではチャー中に水素や酸素は含まれないが, 生成 チャー中へ残留した水素量を生成チャーの元素分析值から アッシュバランスで求めたところ, Fig. 50ように熱分解温度 が高いほど減少し, 圧力が高いほどやや増加する傾向がある ことが分かった。加圧により揮発分は石炭粒子内に滞留しや すくなるために, 生成チャー中に残留する割合が増加すると 考えられる。

\section{2 高温加圧熱分解による生成チャーの性状}

\subsection{1 コーク微粒子の分離とその反応性}

PDTFによる高温加圧熱分解実験において，炉内から等速吸 引でサンプリングした生成チャーは凝集性の高い微粒子を含 んでいた。ここでは，コーク微粒子を含むサンプリングされ た粒子全体を“生成チャー”, 微粉炭粒子中の灰と固定炭素を 由来とするいわゆるチャー粒子を単に“チャー”と呼ぶこと にする。 60 mesh $(250 \mu \mathrm{m})$ の篩で生成チャーを乾式分級し, 電子顕微鏡で観察したところ, Coal SKの例をFig. 6に示すよ うに，いずれの炭種においても篩下にはチャー粒子が多く，篩 上は微粉炭には見られないサブミクロンの球形微粒子が凝集 しており若干量のチャー粒子が微粒子の凝集体に埋もれてい る様子が観察された。従って，乾式篩で分級することにより 大半の微粒子は篩上に残り，簡易的な分離ができたと言える。

各炭種の熱分解生成チャーの篩上と篩下についてTPR法で 反応性を実験した。 $1400^{\circ} \mathrm{C}, 2.1 \mathrm{MPa}$ 熱分解したチャーの実 験結果をFig. 7に示した。3 炭種のうち最も反応性の高いCoal SKでは篩上と篩下の差はほとんどなかったが, Coal WOやBT では篩上凝集微粒子の反応性は篩下チャーよりも明らかに低 かった。この篩上と篩下の反応性の違いはチャーとコークの 反応性の差に起因することが明らかであり, Coal WOやBTの コークは固定炭素由来のチャーよりも反応性が大幅に低いこ とが分かった。 


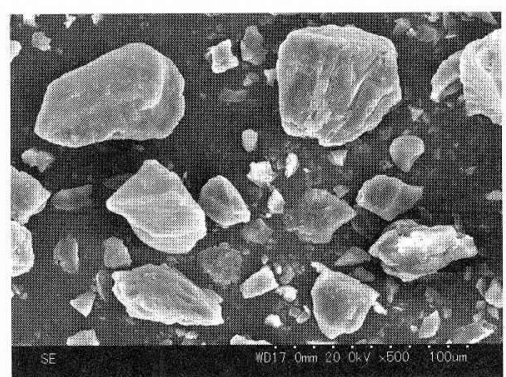

(a) Pulverized coal

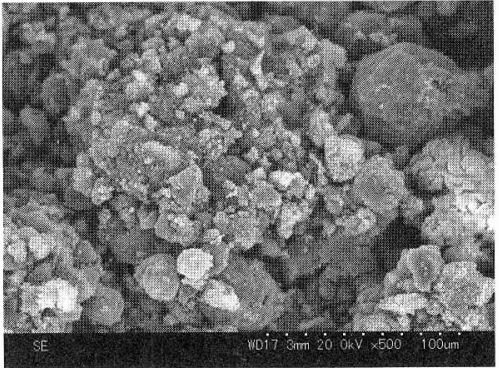

(d) Plus sieved particle from sampled char

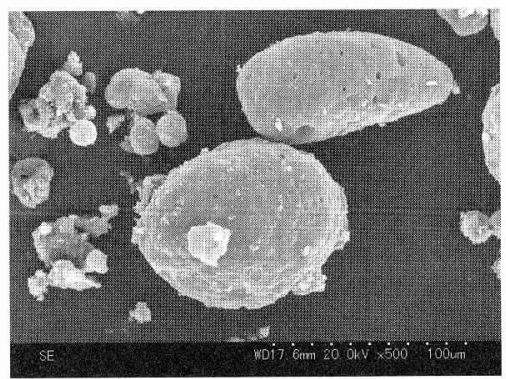

(b) Minus sieved particle from sampled char

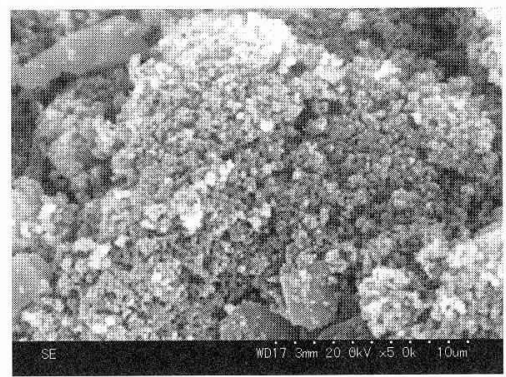

(d) Magnification of photo (c)

Fig. 6 SEM photographs of coal SK and char which was pyrolyzed at $1400^{\circ} \mathrm{C}$ and $2.1 \mathrm{MPa}$ and sieved by $250 \mu \mathrm{m}$ mesh

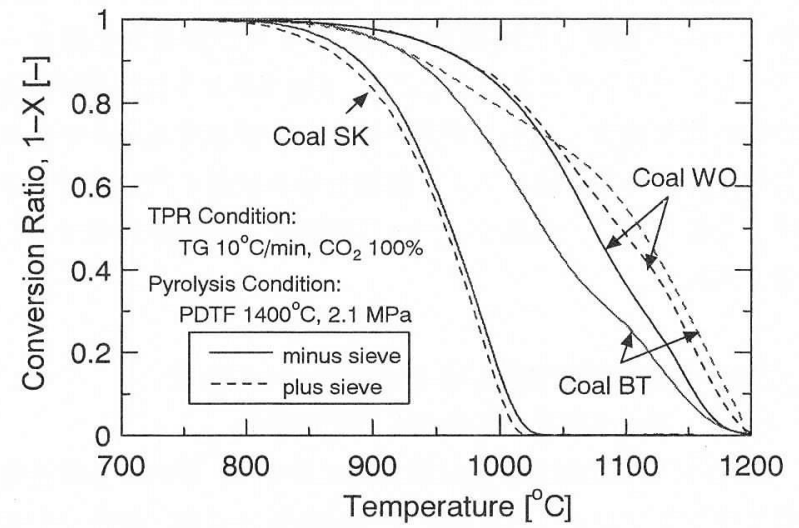

Fig. 7 Gasification reactivity of chars sieved by $250 \mu \mathrm{m}$ mesh

さらに，熱分解温度や圧力がチャーやコークの反応性に与 える影響についてCoal BT の例を Fig. 8 に示した。チャーの 反応性は前報1)の報告と同様に熱分解温度の上昇とともに低 下したが熱分解圧力の影響は小さかった。一方，コークにつ

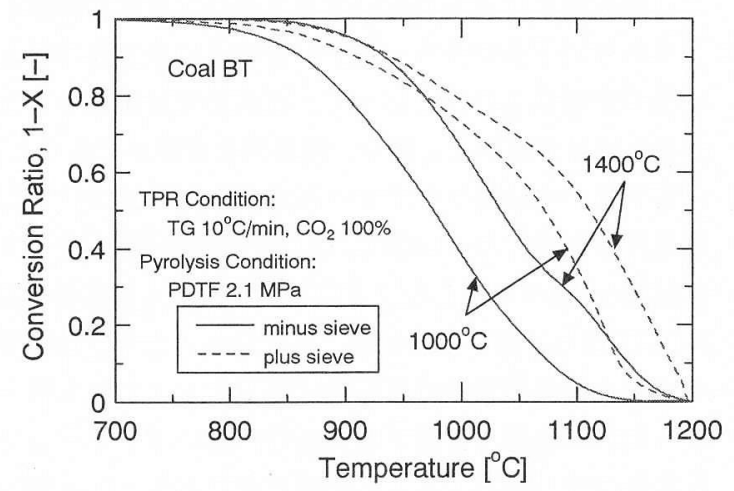

(a) Influence of pyrolysis temperature
いては熱分解温度だけでなく圧力の上昇とともにその反応性 が低下した。特に， $0.15 \mathrm{MPa}$ と $0.6 \mathrm{MPa}$ の間での変化が大き かった。そこで，その理由を検討するためにレーザーラマン によりチャーゃコーク中の炭素構造を測定したところ, 前報1 で報告した通りラマンスペクトルの V/G 值（Gバンドと D バンドの谷 $\mathrm{V}$ と $\mathrm{G}$ バンドの強度比) は熱分解圧力の上昇とと もに若干低下しており，チャー・コークともに炭素の結晶構 造がやや発達したことを示した。しかし， R (=D/G) 值に ついては熱分解圧力の上昇による変化がチャーとコークとで は異なったことから，コークは炭素の結晶構造が加圧により 大きく変化し，そのために反応性が低下した可能性が考えら れる。

チャーと揮発ガスが炉内で分離されるタイプの実験装置で は生成チャー中にコークが含まれることは少ないが, PDTFの ような気流層反応装置では，チャーと揮発ガスが同伴するた め揮発分の二次分解により生成されたサブミクロンのコーク 微粒子がチャーと混在したと言える。噴流床ガス化炉も気流

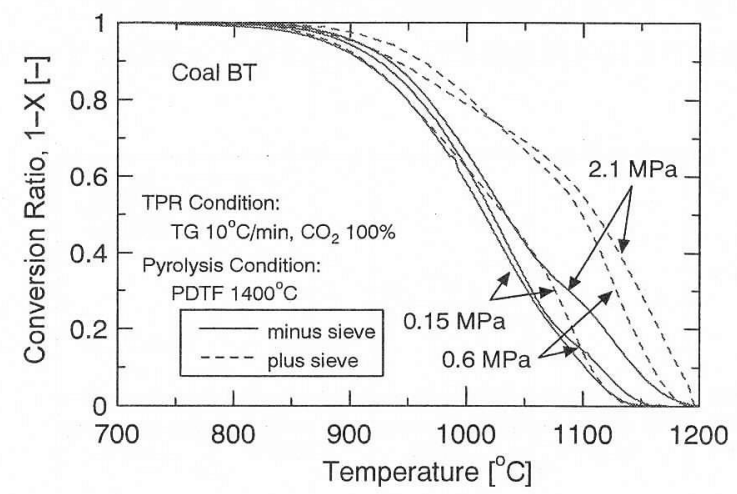

(b) Influence of pyrolysis pressure

Fig. 8 Gasification reactivity of various chars of Coal BT 
層型であり, PDTFの実験と同様にチャー粒子内外にコークが 生成することが予測される。

\subsection{2 コークの生成量}

ガス化反応性の低下を招くコークの生成量は，平衡計算に よる炭素収率と工業分析の固定炭素との差がコーク生成量に 相当すると仮定すると，実験の条件範囲では温度や圧力にほ ぼ因らず Coal WO で 27.3wt\%, Coal SK で 12.5wt\%, Coal BT で $18.6 \mathrm{wt} \%$ と予測される。ただ，急速熱分解でのチャー収 率は固定炭素よりも少ないことが知られているので，さらに 多くのコークの生成が見込まれる。実際に, PDTFの高温加圧

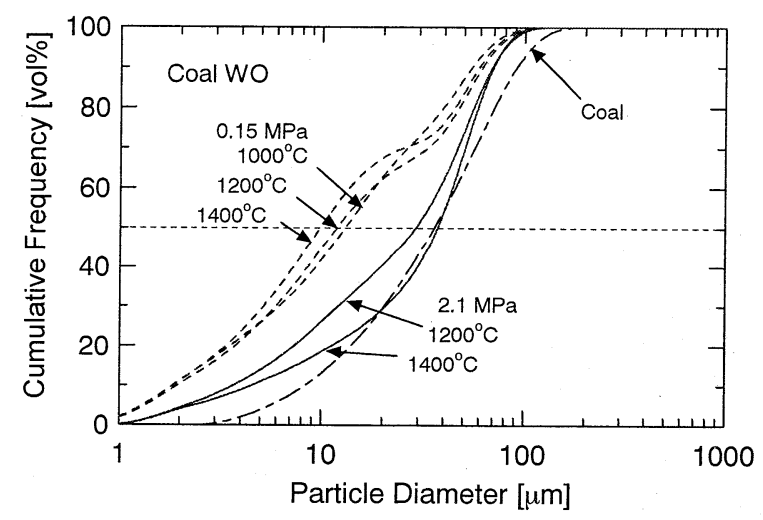

(a) Pulverized coal WO and produced chars

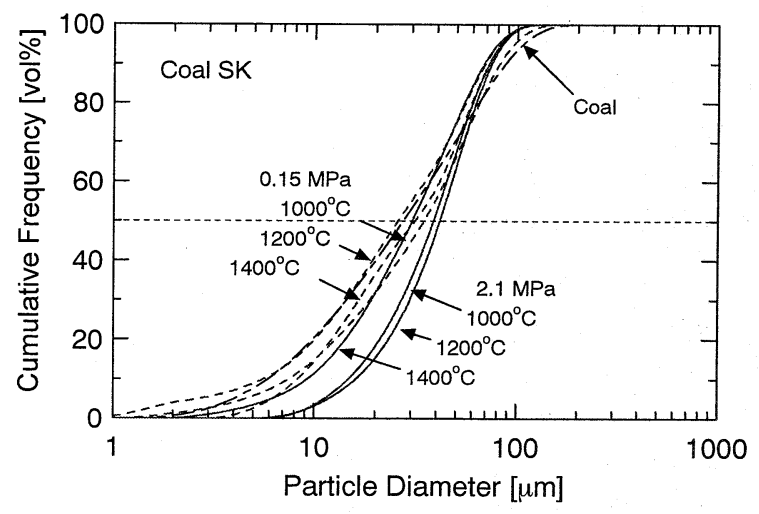

(b) Pulverized coal SK and produced chars

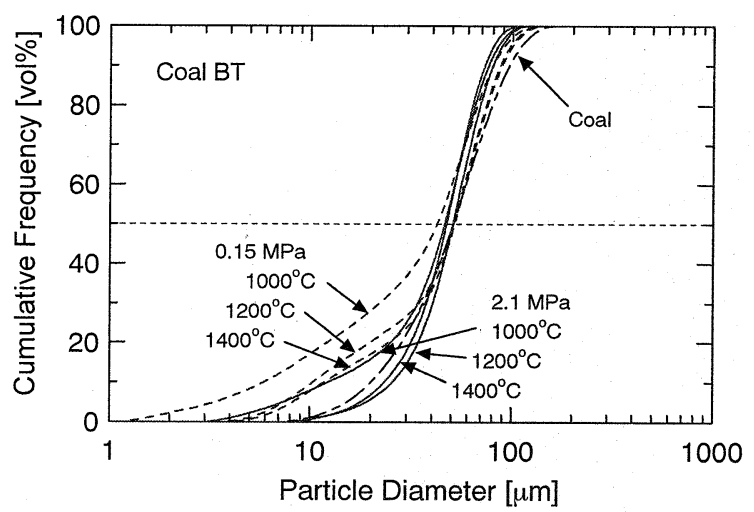

(c) Pulverized coal BT and produced chars

Fig. 9 Particle size distribution of sampled chars (Solid line: 2.1 $\mathrm{MPa}$, broken line: $0.1 \mathrm{MPa}$, dashed line: pulverized coal)
熱分解実験におけるCoal BT の生成チャー中のコーク量を TPR実験結果からMiuraらが見積もったところ，1400 $\mathrm{C} ， 0.15$ $\mathrm{MPa}$ で熱分解した生成チャーでは $68 \%, 1400^{\circ} \mathrm{C}, 2.1 \mathrm{MPa}$ では $60 \%$ に及び7), 平衡計算と工業分析值による上記予測值の 3 倍以上と大幅に多いことが分かった。なお，ここではTPR法 により生成チャーをガス化して, 反応速度が異なる 2 種類の 炭素が存在し Random Pore Model に従うと仮定して解析する ことによりその存在割合を算出した。

そこで，高温熱分解実験でサンプリングした生成チャーの 粒径分布を測定し，コーク生成における熱分解条件の影響を 検討した。ここでは湿式測定のため, 乾式篩では篩上に残っ たコーク凝集体もよく分散した。Fig. 9に示した測定結果のよ うに，3炭種とも熱分解温度にかかわらず2.1 $\mathrm{MPa}$ (図の実線) よりも $0.15 \mathrm{MPa}$ (図の破線) の生成チャーの方が微小粒子の 多いブロードな粒径分布となることが分かった。レーザー回 折法では測定原理上サブミクロンの微粒子は測定できないも のの，生成チャーと篩下チャーの粒径分布と比較したところ， 粒径分布がブロードとなるのは熱分解による微粉炭粒子の膨 張・崩壊よりもコークの存在の寄与が大きいと考えられた。上 述のTPR法による見積もりではコーク生成量の圧力による減 少は 1 ～ 2 割程度にとどまったが，粒径分布ではそれ以上の 変化が見られることから，加圧することにより微粉炭粒子外 への揮発分の放出が抑制されてチャー粒子の内部で生成され るコークが増加し, チャー粒子の外部に存在するコーク微粒 子は減少すると推定される。

\section{3 ガス化剂存在時のコーク生成特性}

ガス化炉内では熱分解実験と異なりガス化剤が存在するた め，揮発分は二次分解と同時に燃焼またはガス化しコークの 生成は抑制されることが期待されることから，PDTFを用いて 希薄酸素中での石炭ガス化実験を実施した。これは実炉内条件 を考慮したもので，例えば空気吹き二段噴流床ガス化炉10111の リダクタではコンバスタからの高温燃焼ガス中に窒素搬送で 微粉炭が投入される。

Coal BTについて $1400^{\circ} \mathrm{C}, 0.6 \mathrm{MPa}$ で実験したときのチャー 中への炭素, 酸素, 水素の残留率をFig. 10に示した。高温熱

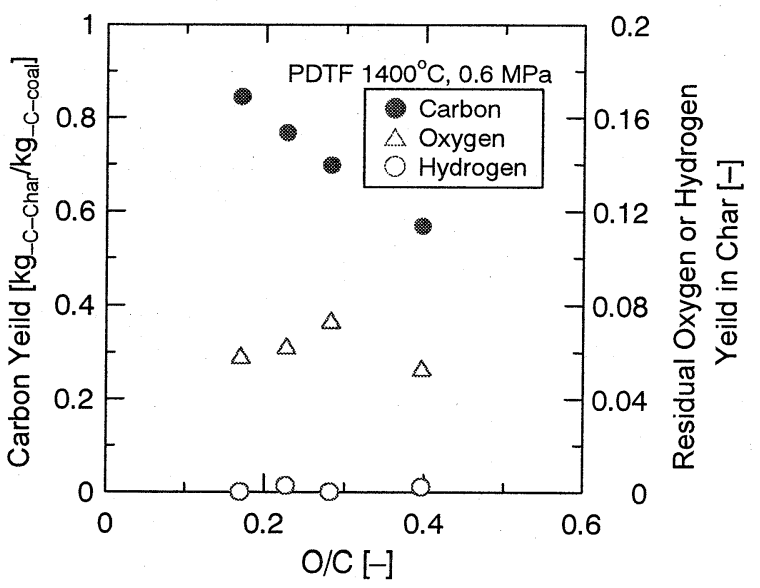

Fig. 10 Pyrolysis and gasification of Coal BT in thin oxygen 


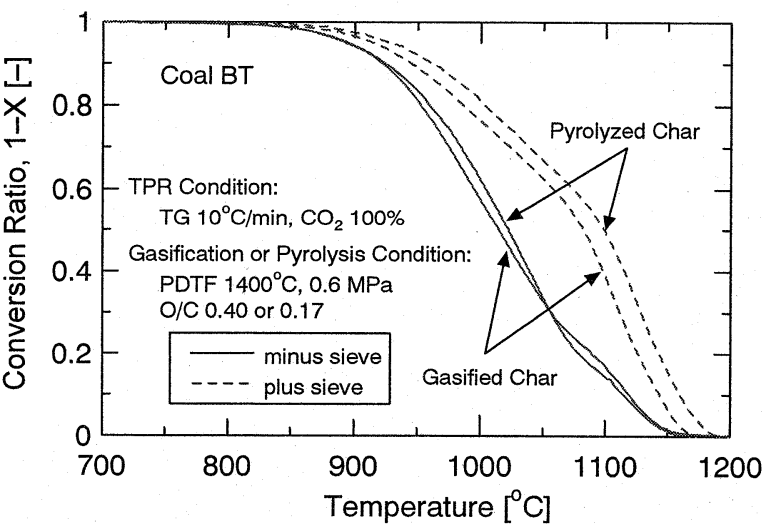

Fig. 11 Gasification reactivity of gasified char sieved by 250 $\mu \mathrm{m}$ mesh

分解実験と同樣な条件で若干量の酸素を供給した。供給ガス を窒素のみ $\left(\mathrm{O}_{2}\right.$ 濃度 $0 \%$ ）として熱分解したときの $\mathrm{O} / \mathrm{C}$ は 0.17 で，O/C が 0.40 のときの供給ガス中 $\mathrm{O}_{2}$ 濃度は $1.7 \mathrm{vol} \%$ である。実験の結果，供給した酸素量に応じて生成ガス $(\mathrm{CO}$ と $\mathrm{H}_{2}$ ) 収率と炭素転換率が上昇し，生成チャー量は減少した。 しかし，このときの生成チャーに含まれるコーク微粒子を前 述の方法と同様に分級して分離したところ，コークの生成が 確認された。O/Cが 0.40 の時の生成チャーをTPR 法でガス 化実験した結果をFig. 11に示したところ，熱分解生成チャー とほほ一致し，大半がコークである篩上凝集微粒子は固定炭 素由来のチャーである穊下チャーよりも大幅に反応性が低い ことが分かった。この結果，ガス化剂の存在下でも反応性の 低いコークが生成することが明らかとなった。

チャー粒子の外部に存在するコーク微粒子はサブミクロン の微粒子であるため，噴流床ガス化炉内ではチャー粒子とは 異なる軌跡を通り滞留時間が短いことが予想され，また，か さ比重や付着性などの粉体特性が異なる。さらにコークのガ ス化反応性がチャーよりも大幅に低い炭種があることが実験 から分かり，ガス化性能予測にはチャーだけでなくコークの 反応速度解析の必要性が示唆された。従って, 噴流床ガス化 炉の設計や性能評価のために炉内現象を検討する上で，コー クの生成挙動は反応性や粉体特性に影響を与える重要な因子 の一つとなる可能性が高いと言える。

\section{4. 結 論}

これまでに報告例の少ない高温かつ加圧条件下における熱 分解特性を検討した。2.1 $\mathrm{MPa}, 1400^{\circ} \mathrm{C}$ までの条件で 3 炭種の 微粉炭についてPDTF を用いた熱分解実験を実施し, 熱分解 生成物収率の圧力影響，コークの生成挙動や性状について，以 下の結果を得た。

1) $1200^{\circ} \mathrm{C}$ 以上の高温熱分解に抢ける生成ガス組成や収率は,
化学平衡による予測值に近くほほCO, $\mathrm{H}_{2}$ のみとなった。一 方，加圧による影響は平衡計算ではほとんどないものの, 実験では圧力が高いほど生成ガス収率が若干減少し生成 チャー収率が増加した。 5 秒程度の滞留時間の場合, 0.15 $\mathrm{MPa}$ と $2.1 \mathrm{MPa}$ の生成ガス収率や生成チャー収率はそれぞ れ約 1 割の差が見られた。

2) 気流層による高温熱分解ではコーク微粒子が生成され，炭 種によってはコークの $\mathrm{CO}_{2}$ ガス化反応性は固定炭素由来の チャーよりも低いことがわかった。また, 熱分解圧力が高 いほどチャー粒子の外部に生成するコーク微粒子は減少す る傾向が見られ，チャー粒子内部に生成することが推定さ れた。

3) 希薄酸素による高温ガス化実験でも $\mathrm{CO}_{2}$ ガス化反応性の低 いコークが生成することが分かり，噴流床石炭ガス化炉の 炉内現象を検討する上でコークの生成は重要な因子の一つ である可能性がある。

\section{謝 辞}

本研究の一部は CCUJ の石炭利用基盤技術開発において行 われたことをここに記します。

\section{文 献：References}

1）梶谷史朗，松田裕光，鈴木伸行，原三郎，化学工学論文集, 30, 29(2004)

2) Kajitani, S., S. Hara, and H. Matsuda, Fuel, 81, 539-546 (2002)

3）梶谷史朗, 芦澤正美, 鈴木伸行, 化学工学会第 36 回秋季 大会エネルギー部会シンポジウム論文集，3,131(2003)

4) Solomon, P. R., Hamblen, D. G., Carangelo, R. M., Serio, M. A., and Deshpande, G. V., Energy \& Fuels, 2, 405 (1998)

5) Fletchar, T. H., Karstein, A. R., Pugmire, R. J., and Grant, D. M., Energy \& Fuels, 4, 54(1990)

6) Stephen Niksa, Gui-su Liua, Robert H. Hurt, Prog. Energy Combust Sci., 29, 425 (2003)

7) K. Miura, H. Nakagawa, S. Nakai, and S. Kajitani, Chem. Eng. Sci., 59, 5261 (2004)

8) C. W. Bale, P. Chartrand, S. A. Degterov, G. Eriksson, K. Hack, R. Ben Mahfoud, J. Melançon, A. D. Pelton, and S. Petersen, Calphad, 26, 189 (2002)

9) G. Eriksson, and K. Hack, Metall, Trans., 21, 1013(1990)

10）犬丸淳, 原三郎，芦澤正美，小林雄一, 浜松照秀, 石川浩, 石神重泰，竹川敏之，日本機械学会論文集 (B編)，57, 12 (1991)

11) Kaneko S., Ishibashi Y., and Wada J., 2002 Gasification Technologies Conference, EPRI, (2002) 